\title{
Kadonnutta erilaisuutta etsimässä - monikulttuurinen musiikkikasvatus ja suomalaiset musiikin oppikirjat
}

Elämme ensimmäistä kertaa maailmanhistoriassa aikaa, jolloin kaikki maailman musiikki on kirjaimellisesti kätemme ulottuvilla. Oikeastaan on osuvampaa sanoa, että joudumme kohtaamaan maailman musiikillisen moninaisuuden joukkotiedotusvälineiden välittämänä, halusimme me sitä tai emme.Tätä taustaa vasten haluan nostaa esille kaksi musiikkikasvatusta koskevaa seikkaa: 1) siihen miten me käsittelemme, opetamme, esitämme tai muutoin "käytämme" maailman musiikkeja täytyy liittyä vastuuta; 2) tämä vastuu ilmenee musiikin opetuksessa esimerkiksi niinä vieraita musiikkikulttuureja koskevina asenteina, joita musiikin oppikirjat välittävät ja niinä didaktisina menetelminä, joita näiden musiikkien opettamisessa käytetään. Tämän kirjoituksen tarkoituksena on valottaa näihin alueisiin liittyvää problematiikkaa.

Vieraiden musiikkikulttuurien opettamiseen liittyvä problematiikka hahmottuu musiikkikasvatuksen kentässä omaksi alueekseen, joka on nimetty monikulttuuriseksi musiikkikasvatukseksi (multicultural music education) ${ }^{1}$. Tavoitteiltaan monikulttuurinen musiikkikasvatus on yhtenevä yleisen kansainvälityskasvatuksen kanssa, ja tarve sen harjoittamiseen on syntynyt samojen yhteiskunnallisten muutosten seurauksena Yhdysvalloissa ja Englannissa, jotka vaikuttivat myös laajemman kansainvälisyyskasvatuksen syntyyn. ${ }^{2}$

Tässä kirjoituksessa monikulttuurista musiikkikasvatusta hahmotellaan kansainvälisissä musiikkikasvatuksen ja etnomusikologian julkaisuissa ilmestyneiden artikkelien perusteella. Erityisesti tarkastellaan sitä, mitä tavoitteita monikulttuurisesta musiikkikasvatuksesta kiinnostuneet musiikinopettajat ja etnomusikologit ovat sille asettaneet, mitä ongelmia he ovat sen toteuttamisessa havainneet ja miten he ovat pyrkineet ratkaisemaan näitä ongelmia. Sen jälkeen analysoidaan sitä, miten kahdessa suomalaisessa musiikin oppikirjasarjassa on lähestytty ei-länsimaisia musiikkeja. Oppikirjojen sisältöä (laulutehtä-

\footnotetext{
${ }^{1}$ Monikulttuurista musiikkikasvatusta ovat suomeksi aiemmin esitelleet Kalli 1991 ja Moisala 1993.

${ }^{2}$ Kansainvälisyyskasvatusta musiikkikasvatuksen näkökulmasta on tutkinut Kalli 1991.
} 
vät, asiatekstit, kuvitus) on tutkittu sisällönanalyyttisin metodein. Tutkitut oppikirjat ovat Hovi-Mäyry-Sipilä: Musica 7 ja 8-9 (Fazer) sekä KasperLampila-Tikkanen: Koulun musiikki 7 ja 8-9 (Otava). Lopuksi tarkastellaan kriittisesti sitä, miten tutkitut oppikirjat heijastelevat kansainvälisessa kirjallisuudessa käsiteltyjä teemoja.

\section{Kansainvälinen monikulttuurinen musiikkikasvatus: "How to make sense of the diversity of world musics?!"}

Jatkossa esitetyt näkökohdat perustuvat vuosien 1981-1991 välisenä aikana seuraavissa julkaisuissa ilmestyneiden artikkelien tarkasteluun: British Journal of Music Education, ISME Yearbook, International Journal of Music Education ja The World of Music. Valitsin kyseiset julkaisut saadakseni kansainvälisesti kattavan katsauksen monikulttuuriseen musiikkikasvatukseen. Mukana ovat kaikki monikulttuurista musiikkikasvatusta käsitelleet artikkelit (yhteensä $23 \mathrm{kpl}$.). Tietyt teemat toistuvat näissä artikkeleissa varsin selkeästi ja toistuvasti. Olen siksi käsitellyt aineistoa tematisoinnin pohjalta enkä artikkelikohtaisesti referoiden. Yksittäisiin artikkeleihin viittaan, jos jokin teema esiintyy niissä selvästi korostuneena, tai jos ne havainnollistavat tiettyä teemaa erityisen selkeästi.

Myös vuoden 1991 jälkeen on toki ilmestynyt monikulttuurista musiikkikasvatusta käsitteleviä kirjoituksia (kts. esim. Lees [ed.]: Music Education: Sharing Musics of The World ISME 1992). Näiden kirjoitusten perusteella monikulttuurisen musiikkikasvatuksen keskeinen problematiikka hahmottuu hyvin samanlaisena kuin tutkimissani ennen vuotta 1991 ilmestyneissä artikkeleissa.

\section{Oppilaiden kulttuurinen/etninen yhtenäisyys vs. erilaisuus}

Monikulttuurisen musiikkikasvatuksen problematiikka määräytyy osittain sen mukaan, millainen oppilaiden kulttuurisen/etnisen yhtenäisyyden ja opetettavan musiikin suhteen oletetaan olevan eli onko kysymyksessä:

1) etnisesti/kulttuurisesti homogeeninen oppilasjoukko, jolle oman kulttuuripiiriin kuuluvan musiikin opettamisen lomassa opetetaan sille vieraan kulttuurin musiikkia. Kysymyksessä on tällöin yleensä ei-länsimaisen musiikin opettaminen länsimaisessa koulussa (kts. esim. Borris 1981; Farrel 1986; George 1987; Hoffer 1988; Kwami 1986 ja 1991; Spencer 1983; Marx 1990). 
2) etnisesti/kulttuurisesti heterogeeninen oppilasjoukko, jonka etninen/ kulttuurinen koostumus osaltaan vaikuttaa opetettavien musiikkien valintaan, jolloin kysymyksessä on yleensä länsimainen monikulttuurinen yhteiskunta ja huoli kulttuuritaustoiltaan erilaisten oppilaiden tasapuolisista oikeuksista vaalia omaa kulttuuriaan. (Kts. esim. Lepherd 1985; Mathias 1985; Anderson \& Shehan Campbell 1989)

3) etnisesti/kulttuurisesti heterogeeninen oppilasjoukko, jolle opetetaan yksinomaan tai pääasiassa musiikkia, joka on kaikille se jäsenille vierasta. Tässä tapauksessa on yleensä kysymys imperialismin rasittamista maista, joissa oppilaat tulevat eri heimoista. Jäänteenä imperialismin ajoista näissä maissa vaalitaan länsimaisen taidemusiikin traditiota, monesti paikallisten alkuperäismusiikkien opettamisen kustannuksella. (Kts. esim. Kwami 1991, Reeder-Lundquist 1987, Orrenmaa 1992 ).

Monikulttuurista musiikkikasvatusta käsittelevässä kirjallisuudessa käsitellään kulttuurista erilaisuutta yllättävän karkein yksiköin. Tarkimmillaan kulttuurisesta erilaisuudesta puhutaan etnisten ryhmien välisenä, karkeimmillaan länsimaisen ja ei-länsimaisen kulttuurin välisenä erona. Kulttuuri on kuitenkin paljon abstraktimpi, hienosyisempi ja herkkärajaisempi asia kuin valtio, yhteiskunta tai edes yhteisö. Vain joissakin erityistapauksissa yhteisö ja kulttuuri voivat olla yhteneviä kategorioita. (Moisala 1991, 109.)

Herndonin ja McLeodin (1981) esittelemän musiikkivaraston käsitteen soveltaminen monikulttuurista musiikkikasvatusta käsittelevässä keskustelussa auttaisi ottamaan huomioon yhteisöjä pienempien ihmisjoukkojen tai jopa ihmisyksilöiden väliset kulttuuriset erilaisuudet. Etnisesti homogeeninen ihmisryhmä, esimerkiksi koululuokka, voi olla kulttuurisesti heterogeeninen.

\section{Monikulttuuriselle musiikkikasvatukselle asetettuja odotuksia}

Monikulttuuriselle musiikkikasvatukselle asetetut odotukset voidaan jakaa seuraaviin kategorioihin sen mukaan, mitä valmiuksia oppilaissa halutaan ensisijaisesti kehittää : 1) kyky kohdata vieraita kulttuureja ja niiden ihmisiä, 2) kyky kohdata vieraita kulttuureja ja niiden musiikkeja, 3) käytännön musiikilliset valmiudet, 4) musiikkikulttuurinen yleissivistys, 5) muut oppilaan hyvinvointia tai hänen kehitystään edistävät seikat ja 6) etnisiin vähemmistöihin kuuluvien oppilaiden kulttuurisen identiteetin ylläpitäminen ja vahvistaminen. 


\section{Kyky kohdata vieraiden kulttuurien ihmisiä}

Monikulttuurisen musiikkikasvatuksen perusteluista syntyy vaikutelma, jonka mukaan monikulttuurinen musiikkikasvatus olisi syntynyt vasta, kun musiikkikasvattajat joutuivat sosiaalisista ja yhteiskunnallisista muutoksista johtuen "nurkkaan ajetuiksi", tilanteeseen, josta ei ollut muuta ulospääsyä kuin maailman musiikillisen kirjon kohtaaminen tavalla tai toisella. Vain harvoin jätetään viittaamatta kahteen meidän ajallemme leimalliseen maailmanlaajuiseen ilmiöön ja niiden seuraamuksiin: pakolaisuuteen ja maahanmuuttoon sekä maailman "kutistumiseen" tiedotusvälineiden välittämän informaatiotulvan ja lisääntyneen matkailun johdosta. Esimerkiksi Hoffer (1988), McKeller (1973), Moisala (1993), Balough (1988) ja Dobbs (1982) pitävät edellä mainittuja maailmanlaajuisia yhteiskunnallisia muutoksia monikulttuurisen musiikkikasvatuksen tarpeellisuuden perustana.

Musiikin katsotaan olevan oivallinen tapa harjoittaa kansainvälisyyskasvatusta näissä olosuhteissa, koska musiikki on erottamaton osa jokapäiväistä elämää kaikkialla maailmassa. Musiikki ei ole universaali kieli, mutta sen rakennusaineet ovat olemassa jokaisessa lapsessa. Eri kulttuurialueiden musiikkien ymmärretään sisältävän keskenään sekä samanlaisia että erilaisia elementtejä. Erilaisuus-samanlaisuus -akseli otetaan käsitteelliseksi lähtökohdaksi opetuksen tavoitteita hahmoteltaessa. Erilaisuuksista voidaan oppia paljon niistä ihmisistä, jotka harjoittavat vierasta musiikkia ja samanlaisuuksista voidaan opetella arvostamaan niitä asioita, jotka ovat eri kulttuureille yhteisiä. Kansainvälisen musiikkikasvatuksen toivotaan kehittävän oppilaissa sellaista suvaitsevaisuutta ja kunnioitusta, joka ilmenee heidän suhteissaan erirotuisten ja toisista kulttuureista tulevien ihmisten kanssa. (Dobbs 1982, 143.)

\section{Kyky kohdata vieraiden kulttuurien musiikkeja}

Jo kauan ennen kuin kysymys monikulttuurisesta musiikkikasvatuksesta tuli ajankohtaiseksi edellä kuvatuista yhteiskunnallisista syistä johtuen, vieraiden musiikkikulttuurien opettamisesta kiinnostuneet ihmiset lähestyivät maailman musiikkeja erilaisuuden ja samanlaisuuden käsitteistä käsin. Australialaissyntyinen konserttipianisti Percy Grainger, joka oli eräs varhaisimmista monikulttuurisen musiikkikasvatuksen puolestapuhujista, kiinnostui vieraista musiikkikulttuureista vietettyään lapsuutensa kulttuurisesti kirjavassa ympäristössä. Vuonna 1932 hän piti New Yorkin yliopistossa luentosarjan "A General Study of the Manifold Nature of Music", jonka tarkoituksena oli esitellä opiskelijoille maailman musiikin päätyypit ja näyttää ne säikeet, jotka yhdistivät maailman eri musiikkeja. Jokainen luento koostui yhdistävästä teemasta tai teemoista (musiikillisesta parametrista), joita käsiteltiin maailman eri musiikeista otettujen soivien näytteiden avulla. (Balough 1988, 74.) 
Viitisenkymmentä vuotta myöhemmin etnomusikologi Kwabena Nketia (1988) kirjoitti vieraisiin musiikkeihin tutustumisesta samalla käsitteistöllä kuin Grainger. Nketian maailma on kuitenkin ratkaisevilta osin erilainen kuin Graingerin. Graingerin aikana kaukaisten kulttuurien musiikki oli varta vasten ja vaivalloisesti haettava kaukaa. Nketia puolestaan esitti ajatuksensa maailmassa, jossa vieraat musiikkikulttuurit 'vyöryvät' päällemme, halusimme me sitä tai emme.

Nketia pitää tämän päivän musiikkikasvatuksen tärkeimpänä tehtävänä antaa oppilaille valmiuksia käsitellä musiikillisen moninaisuuden tulvaa maailmassa, jossa lähes kaikista musiikkikulttuureista on olemassa äänitteitä. Samoihin aikoihin, kun Knetia kirjoitti artikkelinsa (1988), ei-länsimaiset musiikkikulttuurit alkoivat saavuttaa ennen näkemätöntä suosiota Euroopassa ja Pohjois-Amerikassa. Tämä länsimaisen musiikkiteollisuuden vauhdittama ilmiö, jota kutsutaan kaupallisella termillä "maailmanmusiikki-boomi", ajankohtaistaa Nketian huolta maailman musiikillisen moninaisuuden hallinnasta. Hänen ajattelunsa keskiössä on hankalasti suomeksi kääntyvä kysymys: "how to make sense of the diversity that world music presents?". Nketian mukaan on olemassa kolme pääasiallista käsitteellistä lähestymistapaa, joilla tähän kysymykseen voidaan vastata: 1) kulttuuri-relativistien, 2) vertailevan musiikkitieteen edustajien sekä 3) kulttuurienvälisestä kommunikaatiosta ja ymmärryksestä kiinnostuneiden lähestymistavat.

Kulttuurirelativistien mielestä jokaista musiikkikulttuuria tulisi tarkastella sen omilla ehdoilla. Tämä tarkoittaa musiikin oman sisäisen logiikan ja taiteellisten arvojen sekä sen harjoittajien esteettisten, sosiaalisten ja kulttuuristen arvojen huomioon ottamista esimerkiksi opetusta suunniteltaessa. Mitään musiikillista traditiota ei pidä siis arvostella muitten traditioiden kriittisten standardien mukaan. Schwadron $(1984,9)$ mainitsee viimeksi mainitun yhtenä niistä alueista, joihin pitäisi kiinnittää erityistä huomiota monikulttuurista musiikkikasvatusta kehitettäessä.

Komparativistit pyrkivät saamaan mahdollisimman kattavan ja laajan kuvan maailman musiikkikulttuureista. He katsovat maailman musiikkeja panoraamallisesti ja ovat kiinnostuneita niistä suhteista, jotka yhdistävät maailman tai tietyn alueen musiikkeja. Kärjistäen voisi siis sanoa, että relativistit keskittyvät musiikkien erilaisuuteen ja komparativistit niiden samanlaisuuksiin. Kulttuurienvälisestä kommunikaatiosta kiinnostuneet ihmiset sen sijaan keskittyvät niihin rooleihin, joita sekä erilaisuudet että samanlaisuudet näyttelevät kulttuurienvälisessä ymmärtämisessä. Nketia itse pitää tätä viimeksi mainittua lähestymistapaa kaikista mielekkäimpänä. (Nketia 1988, 98-102.)

Toistaiseksi näyttää siltä, että suurin osa nimenomaan musiikilliseen ainekseen kohdistuneesta filosofisesta ja aineellisesta pohjatyöstä monikulttuurisen musiikkikasvatuksen piirissä on tehty muiden kuin musiikkikasvattajien aloitteesta. Tähän on kiinnittänyt huomiota esimerkiksi Borris (1981). Hän perustelee kantaansa ottamalla lähtökohdakseen sellaisten länsimaisten säveltäjien 
musiikin, jotka ovat lainanneet sävellyksiinsä elementtejä ulko-eurooppalaisista kansanmusiikeista. Borrisin $(1981,7)$ mielestä se, että nykyään on helpompi vastaanottaa ja ymmärtää sellaista musiikkia, jossa on yhdistelty eri kansojen musiikkia (infra-national music) tai joka perustuu tavallisuudesta poikkeaville esteettisille periaatteille, on nimenomaan näiden säveltäjien eikä musiikkikasvattajien ansiota.

\section{Käytännön musiikilliset valmiudet}

Vieraita musiikkeja voidaan käyttää myös etydinomaisena materiaalina yhden tai useamman musikaalisuuden osa-alueen harjoittamiseen. Tällöin hyödynnetään sellaisia musiikkikulttuureita, joissa tietyt musiikilliset parametrit ovat korostuneemmassa asemassa kuin omassamme (esim. sointiväri, mikrointervallit ja polyrytmiikka).

Läntisessä maailmassa valtaosa musiikinopiskelusta ja sen harjoittamisesta perustuu musiikin omaksumiseen nuoteista. Dobbs esittää, että kuulonvaraiselle hahmottamiselle ja oppimiselle perustuvien musiikkien opiskeleminen voi tarjota oppilaille kokemuksia toisenlaisille periaatteille perustuvista musisoimistilanteista. Ei-länsimaiset musiikkikulttuurit tarjoavat mielekästä, ilman nuottikuvaa hahmotettavaa materiaalia, jota opiskelemalla voidaan kehittää oppilaiden kuuntelemis- ja reagoimisvalmiutta. Tietenkin myös länsimaista musiikkia voidaan opetella ilman nuottikuvaa. On kuitenkin huomattava, että ei-länsimaisten musiikkien kohdalla notatoitu esitys saattaa joskus jopa vääristää musiikin alkuperäistä ominaislaatua, koska monet näistä musiikeista perustuvat oleellisesti kuulonvaraisuudelle. Nuottikuvan seuraamiseen perustuvan musisoinnin vastapainoksi musiikkia voidaan opetella ilman nuotteja esimerkiksi ryhmän sisällä soittavaa instrumentaalijohtajaa seuraamalla. Nuottikuvasta vapautumisen myötä voidaan vähitellen liikkua kohti improvisaatio- ja sävellysharjoituksia. (Dobbs 1982, 145.)

\section{Musiikillinen yleissivistys}

Maailman eri musiikkien estetiikan ja syntyhistorian tuntemus on nähty itseisarvona. Tämän lisäksi sen on katsottu olevan lähes välttämätöntä sellaisten länsimaisten musiikkityylien syvälliselle tuntemukselle, jotka ovat ottaneet vaikutteita tai suorastaan syntyneet esimerkiksi ulkoeurooppalaisista musiikeista. Esimerkiksi omalla vuosisadallamme sävelletyn musiikin, jazzin, popmusiikin ja rockin ymmärtämiselle on edellytyksenä niiden musiikillisten lähteiden tai niiden syntyyn vaikuttaneen sosiaalisen tilanteen mahdollisimman yksityiskohtainen tuntemus. (Dobbs 1982, 145; Mathias 1985, 14.) 


\section{Musiikillinen itseilmaisu}

Yksi monikulttuurisen musiikkikasvatuksen lähtökohdista on saattaa oppilaat laadullisesti ja tyylillisesti uudenlaisten musikaalisten ilmiöiden äärelle ja näin laajentaa oppilaan musiikillista sanavarastoa. Dobbsin mielestä oppilaan käytettävissä olevien ilmaisukeinojen alue laajenee, kun hän käyttää sellaisia asteikkoja, rytmisiä jaotuksia, sointivärejä, tekstuureita ja rakenteita, jotka ovat hänelle ennalta tuntemattomia. Mielestäni Dobbsin käsitys tosin vaikuttaa hieman idealistiselta. Tietomme bi- tai monimusikaalisuudesta, eli kahden tai useamman musiikkikulttuurin tai -tyylin omaksumiskyvystä ovat varteenotettavien tutkimusten toistaiseksi puuttuessa varsin vaillinaiset (Schwadron $1984,11)$. Mielestäni on selvää, että itsensä ilmaiseminen ratkaisevasti opitusta poikkeavalla musiikillisella sanavarastolla edellyttää kyseisen musiikin "sanaston ja kieliopin" varsin vankkaa hallitsemista eli käytännössä juuri bimusikaalisuutta.

\section{Integroiva opetus}

Useissa ei-länsimaisissa kulttuureissa jako musiikin, tanssin ja muitten taiteiden välillä on olematon tai ainakin selvästi huomaamattomampi kuin omassamme. Niinpä ei-länsimaisia musiikkikulttuureita on käytetty antamaan valmiuksia eri taidemuotojen välisten yhteyksien ymmärtämiseen ja kokonaisvaltaisempien taide-elämysten kokemiseen. (Dobbs 1982, 145.) Pyrkimyksiä tähän suuntaan on kutsuttu integroivaksi taidekasvatukseksi.

\section{Musikaalisuuden laajentaminen}

John Blacking $(1973,4)$ on kuvannut musikaalisuuden käsitettä omassa länsimaisessa kulttuurissamme sanomalla, että meillä valtaosan ihmisistä täytyy olla epämusikaalisia, jotta harvat ja ainoat voivat olla musikaalisia. Tutustumalla sellaisiin kulttuureihin, jossa musiikki ja musikaalisuus kuuluvat kaikille, voidaan saada aavistus siitä, että oma käsityksemme musikaalisuudesta ei ole ainoa tai paras mahdollinen (Mathias 1988). Oma kokemukseni on, että vieraita musiikkikulttuureja opettamalla voidaan saada itseään "epämusikaalisina" pitävät oppilaat osallistumaan aktiivisemmin opetukseen heidän huomatessaan, että ollaan tekemisissä aivan toisenlaisen musiikin kanssa kuin sen, jonka yhteydessä he määrittelevät itsensä tai heidät määritellään "epämusikaalisiksi". 
Sellaisissa maissa, joissa maahanmuutolla on pitkät historialliset juuret, on kysymyksellä etnisten ryhmien oikeuksista ollut ratkaiseva merkitys monikulttuuriseen musiikkikasvatukseen liittyvän keskustelun vilkastumiseen (Lepherd 1985, 48). Yksi osatekijä etnisten vähemmistöjen kulttuurisen identiteetin ylläpitämisessä ja omanarvontunnon kehittymisessä on oikeus ja mahdollisuus vaalia omaa kulttuuriaan myös kouluopetuksessa. Esimerkiksi West Midlandsin alueella Englannissa on mm. intialaisia, karibialaisia ja kiinalaisia yhteisöjä. Joukko muusikoita ja musiikkikasvattajia Birminghamin polyteknisestä korkeakoulusta on järjestäytynyt työryhmäksi, joka organisoi monikulttuurista musiikinopetusta West Midlandsin alueella. Työryhmän toiminnan tuloksena on ilmestynyt kirja, jossa on lista yli 200 muusikosta, tanssiryhmästä, kuorosta ja yhtyeestä. Listan muusikot, jotka vierailevat kouluissa opettamassa ja esiintymässä, edustavat laajaa kulttuurista kirjoa. Tällä toiminnalla halutaan palvella etnisten vähemmistöjen tarpeita, mutta myös tehdä vähemmistöjen kulttuuria tunnetuksi laajemmalle brittiläiselle yhteisölle. (Jackson 1984, 117.)

\section{Yhteenveto}

Vaikka alan kirjallisuudessa vallitsevat näkökulmat vaihtelevat kovastikin, yksi yhdistävä piirre näyttää olevan kirjoittajien kiihkeä halu saada maailman musiikit mukaan koulujen opetusohjelmaan. Olipa painopiste millä tahansa edellä esitellyistä osa-alueista, kirjoittajat eivät voi välttyä ottamasta kantaa siihen, mikä merkitys ja opetuksellinen funktio annetaan opetettavan musiikin erilaisuudelle. Tavallaanhan koko asiasta ei tarvitsisi kirjoittaa, jos ei-länsimaisia musiikkeja ei koettaisi musiikillisesti, esteettisesti ja/tai kulttuurisesti erilaisiksi suhteessa siihen, mitä yleensä opetetaan. Musiikin erilaisuuden elementtiä voidaan korostaa tai väheksyä, sille voidaan antaa virkistys- tai kuriositeettiarvo tai siitä voidaan tehdä joko ongelma tai ratkaisu. Monikulttuuriseen musiikkikasvatukseen liittyvä problematiikka pelkistyykin viime kädessä erilaisuuden kohtaamisen problematiikaksi.

\section{Opettamisen käytäntö}

Vieraiden musiikkien opettamiseen liittyvää käytännön problematiikka tasapainoilee kahden, toistaiseksi vain tangentiaalisesti kohdanneen kysymyksen välissä. Nämä kysymykset näyttävät muodostavan jonkinlaisen noitaympyrän: kuinka kehittää opetusmetodit ja -järjestelmät sekä oppimateriaalit sellaisiksi, että ne edistävät edellämainittujen tavoitteiden saavuttamista, ja 
kuinka samalla lähestyä vieraita musiikkikulttuureita kulttuurisensitiivisesti mainittujen opetusmetodien ja oppimateriaalien toistaiseksi puuttuessa:

Japanese koto music played on the piano with Western harmony or African Ashanti rhythms notated with Western barlines do little to stimulate crosscultural understanding (Schwadron 1984, 11) .

Filosofisten kysymysten ohella on kartoitettu myös niitä käytännöllisiä ongelmia, joihin tulee kiinnittää huomiota, ennen kuin taustalla olevaa filosofiaa päästään syvällisesti ja tehokkaasti harjoittamaan opetuksessa. Osa näistä ongelmista johtuu siitä kehysrakenteesta (vallitseva opetussysteemi, koululaitos, opetussuunnitelmat, opettajainkoulutus jne.), jossa monikulttuurista musiikkikasvatusta harjoitetaan, ja jossa sen osuutta halutaan sekä laadullisesti että määrällisesti kehittää. Monikulttuurisen musiikkikasvatuksen parissa työskentelevillä näyttää vallitsevan hiljainen yksimielisyys esimerkiksi siitä, että oppikirjalla ei voi ja ei tule olla kuin pienenpieni rooli vieraiden kulttuurien opettamisessa. Osa ongelmista liittyy sellaisiin musiikkididaktisiin seikkoihin, joita on käsitelty vähän tai ei ollenkaan, onhan musiikkididaktiset metodimme kehitetty vastaamaan ensisijaisesti länsimaisen musiikin opettamisen tarpeita.

\section{Resurssien puute: instrumentit, opetusmateriaalit ja asiantuntijat}

Erilaisten opetuksellisten resurssien puutteen ratkaisemisessa on kysymys rahoituksesta, etnomusikologisesti ja musiikkikasvatuksellisesti motivoituneiden asiantuntijoiden taloudellisista mahdollisuuksista edistää monikulttuurisen musiikinopetuksen asiaa. Useissa yhteyksissä on toivottu musiikkikasvattajien ja etnomusikologien välistä yhteistyötä opetusmateriaalien kehittämiseksi. Ruotsin valtio tuki jo 1970-luvulla tällaista yhteistyötä tuottamalla Caprice-nimistä äänilevysarjaa, jossa ruotsalaiset etnomusikologit saivat julkaista tutkimusäänitteitään ja -tuloksiaan eri musiikkikulttuureista. Äänilevyihin liittyi laaja ruotsin- ja englanninkielinen tekstivihko, joka antoi musiikinopetukselle tarvittavaa tietoa (Moisala 1993). Iso-Britanniassa on edesmenneen eturivin etnomusikologin John Blackingin aloitteesta koottu vuodesta 1988 lähtien monikulttuurisen musiikinopetuksen tietopankkia. Se sisältää tietoa asiantuntijoista, instituutioista, muusikoista ja opetushenkilöstöstä sekä monikulttuurista musiikkikasvatusta käsittelevistä aineistoista ja opetuspaketeista. (Cook 1990.)

Joissakin kansainvälisissä, lähinnä amerikkalaisten musiikkikasvatuksen aikakauslehtien ja konferenssijulkaisujen artikkeleissa, mennään pelkän pohtimisen, taustatiedon, musiikkinäytteiden tai videomateriaalin tarjoamista pidemmälle. Näissä valitettavan vähälukuisissa artikkeleissa tarjotaan taustatietoa opetettavasta kulttuurista. Lisäksi annetaan käytännön ohjeita instrument- 
tien valmistuksesta, tarjotaan toimivia notaatiovaihtoehtoja ja askel askeleelta eteneviä, yksityiskohtaisia didaktisia neuvoja. On kokonaan toinen asia, missä määrin ammattia harjoittavat musiikinopettajat löytävät tiensä näiden julkaisujen pariin tai pikemminkin missä määrin nämä julkaisut löytävät tiensä musiikinopettajien käsiin. Tämä kaikki on arvokasta materiaalia, koska viime kädessä monikulttuurisen musiikinopetuksen ongelmat ja ratkaisut näyttävät määrittyvän kulloinkin opetettavana olevan musiikin mukaan. Tässä on siis kysymys etnomusikologisen ja musiikkikasvatuksellisen tiedon ja taidon kohtaamisesta.

\section{Musiikkididaktiset menettelytavat}

Länsimaisen musiikinopetuksen keskeisimpiä välineitä on oppikirja, joka sisältää notatoituja esityksiä opetettavasta musiikista. Musiikinopettajaksi opiskellessani olen osallistunut noin 120:lle musiikin oppitunnille joko opetusta seuraten tai itse opettaen. Jokaisella niistä, muutamaa poikkeusta lukuun ottamatta, on ennemmin tai myöhemmin pyydetty oppilaita avaamaan oppikirja, joka sisältää notatoidut esitykset kulloinkin opeteltavista lauluista. Myös kuulonvaraisesti välittyvät musiikinlajit on oppikirjoissa notatoitu.

Länsimaista taidemusiikkia varten kehitetyn notaation käyttäminen usein vääristää musiikkeja, jotka perustuvat ratkaisevilta osin toisenlaisille periaatteille kuin oma musiikkimme. Eräs ensimmäisistä askeleista vieraiden musiikkikulttuurien opettamisen esteenä olevan kynnyksen madaltamiseksi on kuitenkin tehdä musiikki esimerkiksi notatoimalla opetettavammaksi asiaan perehtymättömille opettajille. Varsin tavallista on kehittää oma notaatio opetettavana olevan musiikin mukaan. Toisaalta Mathias kysyy osuvasti : "Kuinka paljon lahjakkuutta on kahlittu vain siksi, että musiikinopettajat ovat pitäneet nuotinlukutaitoa edellytyksenä mille tahansa musiikinopiskelu- ja musisoimisaktiviteetille ja siinä edistymiselle?" $(1985,14$.)

\section{"So many musics, so little time!"}

Kun pohditaan opetettavien musiikkien valitsemisen perusteita, törmätään nopeasti kysymykseen niiden lukumäärästä. Käsitys sopivasta lukumäärästä vaihtelee sen mukaan, mitä monikulttuuriselle musiikkikasvatukselle asetetuista tavoitteista pidetään kaikista tärkeimpänä. Kansainvälisen yhteisymmärryksen kehittämistä korostavat musiikkikasvattajat esimerkiksi ovat yleensä laajahkoon monikulttuuriseen musiikkirepertuaariin perehtymisen kannalla (kts. esim. Balough 1988 ja Hoffer 1988). Moisala ehdottaa, että jokainen opettaja keskittyy yhden tai kahden, itselleen läheisen vieraan musiikin esittelyyn. Hän pitää avainsanana opettajan omakohtaisen kokemuksen ja elämyksen välittymistä oppilaisiin (1993). 
Lukumäärän lisäksi voidaan pohtia sitä, millaisia kriteereitä opetettavaksi valittavan musiikin tulee täyttää. Barbara Reeder-Lundquist esittää $\mathrm{mm}$. seuraavia aspekteja tarkasteltaviksi arvioidessa sitä, onko tietty musiikki sopiva luokkahuoneeseen: 1) musiikillisten materiaalien kompleksisuus, 2) instrumenttien ja muun välineistön saatavuus, 3) soittotekniikat, 4) notaatiosysteemit, 5) oppilasmotivaatio, 6) esitysmahdollisuudet ja 7) mahdollisuus opintojen jatkuvuuteen $(1985,52)$. Tämänkaltaisten kriteerien käyttämisessä piilee se vaara, että ne laaditaan vastaamaan länsimaisen taidemusiikin muovaamia ihanteita ja opetustapoja. Saattaa käydä niin, että vain olennaisesti omaa musiikkiamme muistuttavat musiikit läpäisevät seulan.

Koska on itsestään selvää, että pelkästään yhdenkin musiikkityylin tai -tradition syvälliseen hallitsemiseen voidaan käyttää kokonainen ihmisikä, ratkaisevaan asemaan nousee kysymys siitä, kuinka musiikkia opetetaan. On oletettavissa, että perehdyttyään yhteen vieraaseen musiikilliseen traditioon oppilaan on helpompi tutustua muihin vieraisiin musiikkikulttuureihin.

\section{Opetussuunnitelmat ja musiikinopettajien koulutus}

Vaikka edellä mainitut aineelliset edellytykset olisivat kunnossa ja asian tarpeellisuus virallisestikin tunnustettu, ei kaikki tämä itsestään johda musiikinopetuksen muuttumiseen käytännössä. Esimerkiksi Yhdysvalloissa tarve ei-länsimaisten musiikkien sisällyttämiseen musiikin opetussuunnitelmiin tunnustettiin alustavasti jo 1960-luvun alkupuolella. Siitä huolimatta Schwadron kiinnittää huomiota 'viiveeseen', joka vallitsee konferenssilausuntojen ja opetussuunnitelmien varsinaisen toteuttamisen välillä. Hän viittaa sekä opetuksen sisältöön että sen laatuun:

To date, despite the availability of bibliographies, filmographies, discographies; practical inclusions in school texts; two topical issues of the Music Educators Journal (October 1972 and May 1983); and an increasing (however shaky) rapport with the Society for Ethnomusicology, ISME and UNESCO; the study of music in American schools has not been global in scope, or transevaluative in cultural perspective. $(1984,10$.)

Asiassa ei näytä tapahtuneen merkittävää kehitystä vajaassa kymmenessä vuodessa. Etnomusikologi ja kansanperinteen tutkija Bess Lomax kauhistelee asioiden tilaa vielä syksyllä 1993:

- - I'm really appalled at the fact that we still, after years and years of talking about it, have done absolutely nothing about our including anything except Western music in the public schools of the United States (haastattelu, Brown 1993). 
Tärkeimpänä syynä siihen, että konferenssien ja symposiumien julkilausumat eivät toteudu käytännön tasolla, on Schwadronin mielestä puutteet musiikinopettajien koulutuksessa. Musiikinopettajien koulutusohjelmissa ei ole valmistuttu esimerkiksi varustamaan opiskelijoita valmiuksilla ajatella käsitteellisesti tai opettaa erilaisia musiikillisen kommunikaation systeemejä, arvoja, merkityksiä, funktioita ja esittämistä. Myös Shehan kiinnittää huomiota musiikin opettajien koulutukseen (Shehan 1986, 162). Yhdysvalloissa asiassa on havaitavissa tiettyä kehitystä. Vuoteen 1984 mennessä viidessä yliopistossa oli mahdollisuus opintoihin, joissa yhdistettiin etnomusikologiset ja musiikkikasvatuksen opinnot. Dobbsin (1988) mielestä musiikin-opettajan tulisi paneutua muihin kuin oman kulttuurinsa musiikkeihin osana jokapäiväistä koulutustaan. Pelkät luennot monikulttuurisesta musiikista eivät ole tarpeeksi, vaan musiikkeja on voitava opiskella käytännössä käymällä konserteissa ja soittaen alkuperäisopettajien johdolla. Myös Moisalan (1993) mielestä musiikinopettajille tulisi antaa lisää mahdollisuuksia perehtyä johonkin musiikkikulttuuriin paikan päällä. Toisaalta voidaan myös panostaa etnomusikologien ja eri musiikkien spesialistien yhteistyöhön opetusohjelmia laadittaessa (Mathias 1988 ja Anderson \& Shehan Campbell 1988).

Suomessa on Sibelius-Akatemiassa musiikinopettajiksi opiskelevilla pakollisina aineina lyhyt johdanto maailman musiikkikulttuureihin (1,5 opintoviikkoa) ja pedagogisen etnomusikologian jakso ( 2 ov), joka painottuu jonkin ei-länsimaisen musiikin käytännön musisoinnin taitojen opiskeluun suppean didaktiikan esittelyn lisäksi. Jyväskylän yliopistossa musiikkikasvatusta opiskelevilla on viiden opintoviikon laajuinen "maailman musiikkikulttuurit" kurssi, joka tosin sisältää ulkoeurooppalaisten musiikkikulttuurien lisäksi Suomen kansanmusiikin sekä etnisten vähemmistöjen musiikin, Euroopan kansanmusiikit, rockin, jazzin ja suomalaisen populaarimusiikin. Ulkoeurooppalaisille musiikeille on varattu yksi opintoviikko yhdessä Euroopan kansanmusiikkien kanssa. Oulun yliopistossa "etnistä musiikkia" opetetaan osana kuoro- ja orkesteriopintojen ja musiikintuntemuksen opintokokonaisuuksia (yhteensä 3,5 opintoviikkoa).

Nykyinen opetus antaa siis valikoivasti tietoa eri musiikkikulttuureista ja suppean käytännön kosketuksen jonkin vieraan musiikin tuottamiseen. Sibelius-Akatemiassa mahdollisuudet etnomusikologian syventävien opintojen aloittamiseen on lukuvuoteen 1994-95 mennessä tarjottu vain yhtenä lukuvuonna. Syventymiskohteen opinnot etnomusikologiassa on suorittanut yhteensä kymmenen opiskelijaa.

\section{Suositeltuja opetusstrategioita}

Laajalti ollaan yhtä mieltä siitä, että kulttuurisen kontekstin luominen on lähtökohta monikulttuurisessa opetustapahtumassa riippumatta siitä, millai- 
sin musiikkididaktisin ratkaisuin jatkossa edetään. Laajimmillaan kontekstin luominen on integroivaa opetusta, muiden oppiaineiden tietoja sekä opettajien resursseja hyödyntävä ja yhdistelevä prosessi, suppeimmillaankin kyseisen musiikkikulttuurin historian esittelemistä.

Suositeltavana lähtökohtana pidetään uusien musiikkien käsittelemistä kaikille musiikeille yhteisten musiikillisten käsitteiden avulla. Monet monikulttuurista musiikinopetusta harjoittaneet opettajat rakentavat esimerkiksi melodiasta, rytmistä, tekstuurista, sointiväristä, dynamiikasta ja muodosta käsitteellisen kehikon, jonka ympärille voidaan järjestää laaja kirjo musiikillisia kokemuksia (Anderson \& Shehan Campbell 1988, 5). Koska nämä elementit ovat tuttuja myös omassa musiikissamme, voidaan niiden avulla rakentaa silta opiskelijoille tutulta maaperältä vieraalle esittämällä esimerkiksi seuraavanlaisia kysymyksiä: "Kuinka intialainen musiikki liikkuu musiikillisessa ajassa, länsimaisen funktionaalisen harmonian puuttuessa? Kuinka siinä saadaan aikaan esimerkiksi seuraavat musiikilliset ilmiöt: yhtenäisyys-variointi, jännitys-purkaus, kliimaksi, balanssi, jatkuvuus?" On todennäköistä, että tämän lähestymistavan myötä ilmaantuu pian muita monikulttuurisen musiikkikasvatuksen kannalta oleellisia kysymyksiä: 'Mitä on musiikki? Mitä on 'hyvä' musiikki? Mitä on musikaalisuus?" (Schwadron 1984, 11.)

Toinen tutusta tuntemattomaan johtavan sillan rakentamiseen perustuva lähestymistapa on ottaa lähtökohdaksi kaiken musiikin sidonnaisuus ympäröivään kulttuuriin. Tämän kulttuurisensitiivisen tai musiikkiantropologisen lähestymistavan puitteissa voidaan tarkastella esimerkiksi sitä, miten musiikin esteettiset arvotukset syntyvät, miten ääniteteollisuus, kaupallisuus, kansallisuusaate, ideologiat, yhteisön rakenne, kirjakielisyys kontra muistinvaraisuus, kansojen liikkuminen, kulttuurin oma aikakäsitys jne. vaikuttavat musiikin laatuun. Tällöin musiikkiin ei tutustuta länsimaisen musiikinteorian perusparametreista käsin vaan enemmän sen omilla ehdoilla. (Moisala 1993.)

\section{Ei-länsimainen musiikki suomalaisissa musiikin oppikirjoissa}

Olen analysoinut Fazerin ja Otavan kustantamat musiikin oppikirjat 7-9 luokille sisällönanalyyttisin keinoin. ${ }^{3}$ Aineisto on jaettu kolmeen luokitusyksikköön: musiikillinen aines, soitto- ja laulutehtävät, asiatekstit ja kuvitus. Kutakin luokitusyksikköä varten on luotu sisältöluokkia, joiden avulla kirjojen sisältö on eritelty. Musiikillisen aineksen kohdalla tarkasteltiin kunkin laulun alkuperämaata, tyylilajia, sanoitusten kieltä (alkuperäiskieli/suomennos) ja ennen muuta musiikillista esitystä ja käsittelyä (sovitus, soitinnus,

${ }^{3}$ Oppikirjojen sisältöanalyysi on kuvattu tarkemmin tutkielmassa, johon tämä kirjoitus perustuu, ks. Antikainen 1993, 31-56. 
oheistehtävät jne.) Asiatekstiosuuksia käsittelevässä osuudessa tarkasteltiin seuraavien teemojen esiintymistä ja niiden suhteellista painottumista kunkin esiteltävän musiikkikulttuurin kohdalla: 1) musiikin yhteys ympäröivään kulttuuriin, 2) musiikkikulttuurin historia, 3) soittimet, 4) yhteys länsimaihin, 5) muusikot \& säveltäjät, 6) vaikutteet muista musiikkikulttuureista, 7) yhteys muihin taiteisiin, 8) musiikin kuvailu.

Kuvitusta tarkasteltiin sekä aiheen mukaan että laadullisesti. Kuvien aiheet muodostivat seuraavat seitsemän sisältöluokkaa: 1) muusikot, 2) soittimet, 3) kaupunkiympäristö, 4) luonto, 5) kylä/maaseutu, 6) muu kulttuuri tai yhteiskunta ja 7) juhlat tai rituaalit. Kuvien laadun erittelyä varten käytettiin kolmea sisältöluokkaa: 1) informatiivinen, 2) dekoratiivinen, 3) stereotyyppinen. Kuvat sijoittuivat sisältöluokkiin sen mukaan, mikä niiden tehtävä on suhteessa vastaavaan asiatekstiin, tai miten kiinteästi ne liittyivät siihen.

Laadultaan informatiivisiin kuviin lukeutuvat kaikki sellaiset kuvat, jotka liittyvät kiinteästi vastaavaan asiatekstiin. Ne joko havainnollistavat asiatekstissä esitettyjä tietoja tai kuvatekstillä varustettuina syventävät opeteltavan asiakokonaisuuden omaksumista. Dekoratiivinen kuvitus liittyy löyhästi asiatekstissä käsiteltävään aihepiiriin, mutta tekstistä ei voida osoittaa mitään tiettyä kohtaa, johon kukin kuva liittyisi. Funktioltaan dekoratiivinen kuvitus on tyypillisesti sellaista, joka miellyttää silmää esteettisesti ja täyttää muutoin tyhjän tilan tekstipalstojen ja laulujen välissä sekä sivujen nurkassa.

Laadultaan stereotyyppistä kuvitusta voisi kutsua myös "matkailumainoskuvitukseksi". Se liittyy käsiteltävään aihepiiriin mutta niinkuin dekoratiivisen kuvituksenkin, sen tehtävä on ensisijaisesti miellyttää katsojan silmää. Se pyrkii antamaan kuvaamastaan kohteesta kliseisen, vallitseviin kulttuurisiin stereotypioihin perustuvan ja edelleen niitä ylläpitävän mielikuvan. Sen kuvaamaa todellisuutta ei ole olemassa kuin matkailumainoksissa. Kategorioiden välisiä suhteita voisi pelkistäen kuvata esimerkiksi näin: dekoratiiviset kuvat eivät ole samassa määrin asiallista tietoa antavia kuin informatiiviset, mutta eivät myöskään yhtälailla "klisee-ajatteluun" rohkaisevia kuin stereotyyppiset kuvat. Asiatekstiin liittymätön kuvitus ei ole vain harmitonta ja turhaa, vaan se saattaa olla vaikutukseltaan kulttuurisia stereotypioita vahvistavaa ja eksotiikallaan aktiivisesti etäännyttävää. Vastaavasti luonteeltaan informatiivinen kuvitus voi paitsi toimia kontekstia luovana ja musiikin kokonaisvaltaista oppimista tukevana elementtinä myös ennakkoluuloja muokkaavana tekijänä.

\section{Kadonnutta erilaisuutta etsimässä}

Kansainvälisessä keskustelussa ja kirjoituksissa monikulttuurisen musiikkikasvatuksen problematiikka pelkistyy kysymykseksi siitä, millä tavalla kohdata tai antaa oppilaille valmiuksia kohdata kulttuurista ja musiikillista erilaisuutta. Siksi olen pyrkinyt tarkastelemaan analysoimiani oppikirjoja kysy- 
mällä, vievätkö ne oppilaita lähemmäksi opetettavaa kulttuuria vai loitontavatko ne oppilaita siitä. Keskeisin huomioni on, että tarkastelemissani oppikirjoissa ei-länsimaiset musiikkikulttuurit on erilaisin toimenpitein käsitelty siten, että problematiikka erilaisuuden kohtaamisesta ei pääse edes aktualisoitumaan. Kansainvälisen monikulttuurisen musiikkikasvatuksen yksi toistuvista käsitteistä on adaptaatio, oppilaiden sopeutuminen uudenlaisiin kulttuurisiin ja esteettisiin arvoihin. Sekä musiikillisen materiaalin valinnalla ja käsittelyllä että asiateksteillä ja kuvituksella on tutkimissani kirjoissa varmistettu se, että adaptaatiota ei voi oppilaiden "päässä" syntyä, sillä tietynlainen adaptaatio on tapahtunut jo kirjantekovaiheessa: "ruoka" on ikäänkuin pureksittu valmiiksi. Käsittelen seuraavassa niitä keinoja, joiden avulla vieraiden kulttuurien musiikki on suomalaisissa musiikin oppikirjoissa muokattu helpommin nielaistavaan muotoon.

\section{Laulujen musiikkikulttuuriset taustat}

Oppikirjoihin sisällytetyt laulut muodostavat siinä määrin vakiintuneen osan länsimaista ja suomalaista musiikkiohjelmistoa, että musiikillisen erilaisuuden kohtaamista ei tapahdu. Jos viesti kansainvälisen keskustelun perusteella määrittyvän monikulttuurisen musiikkikasvatuksen takana on, että "tällä tavoin järjestettyä ääntä kutsutaan musiikiksi maailman toisella puolen", vastaava viesti suomalaisten oppikirjojen ei-länsimaisia musiikkeja käsittelevän osuuden taustalla olisi: "Tiesittekö, että tämä kaikkien tuntema laulu onkin kotoisin maailman toiselta puolelta?"

Tämä havainto on sopusoinnussa Smedsin tutkimuksen kanssa, jonka mukaan kirjantekijät haluavat valita kirjoihin lauluja, jotka ovat tunnettuja sekä kotimaassaan että Suomessa $(1991,70$.) Taipumusta valita kirjoihin suomalaiseen musiikkirepertuaariin jo vakiintuneita lauluja, havainnollistaa osuvasti se, että esimerkiksi neljä Musican kaiken kaikkiaan kuudesta ei-länsimaisesta laulusta on sisällytetty Fazerin Suureen toivelaulukirjaan. Sen alkusanoissa todetaan laulujen valintaperusteista näin:

Olemme pyrkineet valitsemaan Suureen toivelaulukirjaan vain sellaisia lauluja, joilla on jo taattu sijansa Suomen kansan tai sen jonkin osan sydämessä ja joita siten todella voisi nimittää suomalaisiksi toivelauluiksi." (Suuri toivelaulukirja, 1976). (Kursivointi kirjantekijöiden.)

Vaikka laulut eivät kuuluisi kaikkein tyypillisimpään länsimaiseen musiikkirepertuaariin, ne edustavat lähes poikkeuksetta sellaisia musiikkikulttuureita, jotka ovat jo pari sataa vuotta sitten sekoittuneet länsimaiseen, eurooppalaiseen musiikkiin. Esitän seuraavassa muutaman asiaa valaisevan esimerkin: 
Koulun musiikki -sarjan yläasteen kirjoissa olevista 16 ei-länsimaisesta musiikkikulttuurista peräisin olevasta laulusta peräti 13 on kotoisin Etelä- tai Väli-Amerikasta, jonka musiikin sekoittuminen eurooppalaiseen musiikkiperinteen kanssa tapahtui jo löytöretkeilijöiden aikaan. Esimerkiksi 7. luokan kirjassa perulaista musiikkia edustavat laulut "Vain kotka lentää aurinkoon" ja "Fiesta Aymara". Voidaan siis sanoa, että Koulun musiikissa esiteltävä perulainen musiikki onkin perulaisia aineksia omaksunutta eurooppalaista musiikkiperinnettä, joka on "paluumatkalla" Perusta takaisin Eurooppaan.

Venezuelasta ja Uruguaysta on kummastakin yksi laulu ("Marakatti" ja "Merimiehen romanssi"). Eurooppalaisella kulttuurilla on ollut voimakas vaikutuksensa myös venezuelalaiseen ja urugualaiseen kansanmusiikkiin. Selvyyden vuoksi sanottakoon, etten suinkaan halua väittää, että esimerkiksi edellä mainitut eteläamerikkalaiset laulut olisivat eurooppalaisaineksiensa takia jollain tavalla "epäaitoja", mitä ikinä se tarkoittaakin. Haluan kiinnittää huomiota laulujen alkuperään liittyen tutkimieni kirjojen ohjelmiston sijoittumiseen tuttuus-vieraus -akselilla.

Laulutehtävät eli toiminnallinen musiikkiin perehtyminen oppikirjoissa vähenee sitä mukaa, kun käsiteltävän musiikin estetiikka etääntyy oman musiikkimme estetiikasta: siirryttäessä Latinalaisen Amerikan musiikista afrikkalaisen musiikin kautta aasialaiseen musiikkiin soitto- ja laulutehtävien määrä vähenee radikaalisti. Molemmissa kirjoissa laulu- ja soittotehtävien puute on "korvattu" kuunteluesimerkkien sisällyttämisellä kuuntelukasetille. Laulujen suhteellisen suuri osuus verrattuna asiatekstiosuuteen saattaa latinalaisamerikkalaisen musiikin kohdalla osittain selittyä sillä, että sitä käsitellään pääasiassa seitsemännellä luokalla, jolloin asiatekstien osuus on selvästi haluttu pitää pienenä.

Oppikirjojen sisältämä laulusto tietenkin määräytyy osittain valtakunnallisten opetussuunnitelmien mukaan. Jätän kysymyksen opetussuunnitelmien ja kirjantekijöiden tekemien valintojen suhteesta käsittelemättä varsinaisten tutkimuskysymysteni ulkopuolelle jäävänä problematiikkana.

\section{Sovitukset}

Vaikka esiteltävässä musiikissa olisi esteettisesti vieraita elementtejä, ne saatetaan sovituksellisella käsittelyllä sellaiseen muotoon, että ne eivät häiritse länsimaiseen estetiikan piirissä enkulturoitunutta oppilasta. Molemmissa kirjoissa sovitusten lähtökohtana näyttää olevan soitinkokoonpano, joka sisältää nk. bändisoittimet, kitaran, basson ja rummut. Musicassa ei ole laulukohtaisia sovituksia vaan kirjan lopussa on joukko "peruskomppeja". Jokaiselle laululle on osoitettu yksi näistä kompeista. Tällainen kirjantekijöiden ratkaisu viittaa sellaiseen sovituslähtöiseen "valitaan laulut sovituksia varten" -ajattelutapaan, jonka mukaan laulujen valinta on alisteista sille, sovel- 
tuvatko ne esitettäviksi länsimaisesta viihde- ja popmusiikista käsin määrittyvälle soitinkokoonpanolle. Koska on itsestään selvää, että esimerkiksi perinteistä japanilaista tai kiinalaista musiikkia ei voida esittää shuffle- tai triolikompin säestyksellä, kirjan tekijät ovat päättäneet olla sisällyttämättä laulutehtäviä näistä maista.

\section{Asiatekstit: länsimainen mies ja huono omatunto}

Varsinkin Musican asiateksteissä painotetaan sellaisia alueita, joita länsimaissa tavataan arvostaa, vaikka ne opetettavan (nykypäivässä elävän) musiikin oivaltamisen kannalta ovat toissijaisia. Koulun musiikin asiateksteissä lähestytään musiikkikulttuurien edustamaa erilaisuutta huomattavasti kulttuurisensitiivisemmin, mutta se mitä stereotypioita välttelevällä tekstillä saavutetaan, menetetään eksotiikkaa viljelevällä ja yksipuolistavalla, etäännyttävällä kuvituksella. Kuvituksella rohkaistaan oppilaita näkemään tutustumisen kohteena olevat kulttuurit turistin silmin eksoottisina ja hyvin yksiulotteisina kohteina. Esteettiselle käsityskyvylle haasteellista erilaisuuden kohtaamista vältetään, ja "kulttuurishokkia" ennaltaehkäistään edellämainituin toimin niin yliampuvasti, että esiteltävä kulttuuri usein vääristyy länsimaisia kulttuurisia stereotypioita vastaavaksi "turistikohteeksi". Kuvitusta käsitellään erikseen myöhemmin.

Etäännyttämistä ja kahtiajakoa länsimaiden ja ei-länsimaiden välillä lisää myös varsinkin Musican asiatekstiosuuksissa esiintyvä toistuva länsimaisen musiikin esitteleminen perinteisiä ei-länsimaisia musiikkeja uhkaavan kulttuuri-imperialismin välineenä. Nämä tekstijaksot saavat kuitenkin yleensä kaikkia tyydyttävän "onnellisen lopun"; länsimainen musiikki päästetään kulttuuriimperialistisesta roolistaan lopettamalla jakso esimerkiksi kappaleeseen, jossa todetaan käsiteltävän maan ryhtyneen toimiin oman musiikkinsa säilyttämiseksi ( kts. esim. s. 177, 'Kiina", suorastaan länsimaista otetun esimerkin ansiosta! ja s. 183, "Afrikan urbaani populaarimusiikki".) Vaikka tarkoitus saattaa olla hyvä, tämän näkökulman toistuvalla alleviivaamisella pikemminkin vahvistetaan mielikuvaa länsimaiden ja sen musiikin ylivoimaisuudesta. Tuloksena on siis tietynlaisen darwinistinen "heikot sortuu elontiellä, vahvat senkun porskuttaa" -ajattelun vahvistaminen. Jos ei-länsimaisia musiikkeja lähestytään oppikirjassa pääasiassa ja johdonmukaisesti alleviivaamalla sitä uhkaa, jonka länsimainen musiikki on niille aiheuttanut eri aikoina, saattaa hyvää tarkoittaen tehty valistus kääntyä itseään vastaan; länsimaiden ja länsimaisen musiikin hegemonian toistuva esiintuominen saattaa niiden kanssa kontaktissa olevat ei-länsimaiset musiikkikulttuurit passiivisen ja heikon vastaanottajan rooliin. Tällainen asetelma havainnollistuu hyvin vertailemalla esimerkiksi sitä, miten Musicassa ja Koulun musiikissa käsitellään Saharan eteläpuolisen Afrikan urbaania populaarimusiikkia. (Koulun musiikki 8-9, s. 52-53). 
Kirjan tekijöiden tekemät näkökulmanvalinnat korostuvat asiatekstien lyhyyden takia. Historiallisen näkökulman valitseminen pääasialliseksi käsittelytavaksi on huomionarvoinen ratkaisu kirjan tekijöiltä, sillä se merkitsee etääntymistä tämän päivän musiikillisesta maailmasta ja siitä soivasta ympäristöstä, jossa esiteltävän kulttuurin ihmiset nykyaikana elävät. Historiaan pohjaava näkökulma kertoo vähän tai ei mitään siitä, minkälaista kyseisessä kulttuurissa elävien ihmisten musiikki on nykypäivänä: missä sitä esitetään, ketkä sitä esittävät jne. Lisäksi historiallinen lähestymistapa sulkee käsittelystä pois sellaiset musiikit, joilla ei ole kirjoitettua historiaa. Käytännössä tämä ilmenee Musica-kirjoissa siten, että esiteltäväksi on valittu korkeakulttuurin piirissä syntyneitä musiikkeja, aina kun se on mahdollista. Niinpä esimerkiksi Japani ja Kiina esitellään yksipuolisesti vanhan, historiallisen musiikkikulttuurin tyyssijana, kun taas afrikkalaisesta heimomusiikista hahmotellaan kuvaa täysin historiattomana, musiikin käyttöyhteyksien ja soitinluettelon kautta määrittyvänä ilmiönä. Musicasta välittyy mielikuva, jonka mukaan Japanissa ja Kiinassa ei enää nykypäivänä ole musiikkia ollenkaan, kun taas Afrikassa ei ole ollut musiikkia ennen meidän päiviämme. Toisaalta sisällyttämällä tekstiin alkuperäiskansojen myyttisiä tarinoita ja uskonnollisia kertomuksia oppikirjan tekijät ovat mahdollistaneet "historiallisen" näkökulman sellaistenkin kulttuurien kohdalla, joilla ei ole kirjoitettua historiaa (kts. esim. Koulun Musiikki 7, 130, Inkojen musiikki ja Koulun Musiikki 8-9, 259 Reggae). Tämä ei tietenkään kerro välttämättä mitään siitä musiikista, jota kyseisessä maassa esiintyy nykyään, mutta säännönmukaisesti sovellettuna se saattaa luoda kulttuurin omista lähtökohdista syntyvää kontekstia esiteltävälle musiikille.

Ei-länsimaisiin musiikkikulttuureihin perehdyttäminen valottamalla niiden historiallisia ja muita suhteita länsimaihin, on mielestäni hyvin kyseenalainen ratkaisu. Se johtaa helposti käsitykseen, jonka mukaan koko maailma ja sen musiikit määrittyvät ensisijaisesti länsimaiden kautta. Voidaan tietysti väittää, että pedagogisesti ajateltuna on oikein tehdä omasta kulttuurista kiintopiste, johon lapsi tai nuori voi verrata uudesta kulttuurista saamaansa informaatiota. Tämä on kuitenkin osattava tehdä taiten; millä tavalla esimerkiksi Musican opettajan materiaalissa tarjottu luettelo aasialaissyntyisistä muusikoista valottaa Aasian omaa musiikkia, kun kaikki luettelon taiteilijat ovat tulleet kuuluisiksi nimenomaan länsimaisen taidemusiikin esittäjinä? Asetelman vinoutuneisuutta voidaan havainnollistaa kuvittelemalla musiikin oppikirjaa, joka esittelisi länsimaista taidemusiikkia pääasiassa suhteessa japanilaiseen hovimusiikkiin tai jaavalaiseen gamelan-musiikkiin.

\section{Musiikkididaktiset lähestymistavat}

Kun tutkitaan sitä, miten oppikirjoissa tehdyt ratkaisut heijastelevat kansainvälisessä kirjoittelussa esiintyvää kulttuurisensitiivisyyden vaatimusta, on 
yhtä oleellista tutkia sitä, mitä kirjoista ei löydy kuin sitä mitä niissä on. Kansainvälisen monikulttuurisen musiikkikasvatuksen suosituksista, joita suomalaisissa oppikirjoissa ei ole sovellettu, mainittakoon esimerkiksi musiikkikohtaisesti kehiteltyjen notaatiosysteemien käyttö ja kuulonvaraiseen opetteluun perustuva musiikin omaksuminen. Myöskään sellaista lähestymistapaa, jossa musiikkia kuin musiikkia lähestytään kaikille musiikeille yhteisten parametrien (melodia, rytmi, sointiväri jne.) kautta, ei ole sovellettu. Näyttää siltä, että ollakseen oppikirjakelpoinen, musiikillisen materiaalin on oltava bändisoittimilla säestettävä säkeistölaulu. Jos musiikillinen materiaali on oleellisesti sellaista, että nuo ehdot jäävät täyttymättä, sitä joko muokataan tarvittavilta osin tai jätetään kokonaan pois kirjasta.

Mitä laulujen valintakriteereihin tulee, Fazerin kustantamassa Musicassa suuri merkitys näyttää olevan myös sillä, kenellä on laulun kustannusoikeudet. Kaikkien sellaisten laulujen, joilla ylipäätään on copyright-suojaus, suomalainen kustannusoikeus on Fazer Musiikki Oy:llä.

Länsimaisen notaation kyseenalaistamaton käyttö ainoana musiikin opettelun välineenä määräytyy pikemminkin musiikinopettajan kuin keskiverto-oppilaan valmiuksien perusteella. Sitäpaitsi jos opetettavana on vieraan musiikkikulttuurin laulu, ei pelkkä sointumerkeillä varustettu ja nuotinnettu esitys pysty välittämään laulun musiikillista erityislaatua. Valtaosa maailman musiikista periytyy sukupolvelta toiselle edelleenkin kuulonvaraisesti.

Oppikirjojen tekijät näyttävät tunnistaneen kansainvälisessä musiikkikasvatuksessakin käsitellyn kysymyksen siitä, pyrkiäkö mahdollisimman kattavaan esitykseen vai keskittyäkö yhden tai kahden musiikin perusteellisempaan esittelyyn. Kattavuuteen on pyritty esimerkiksi luettelonomaisilla esityksillä vaikkapa tietyn musiikkikulttuurin soittimista. Vaikka tämä ratkaisu on puolustettavissa jonkinlaisen kattavuuden saavuttamisena, se ei ole täysin riskitön. Tekstiosuudet ovat niin lyhyitä, että niiden puitteissa ei ole mahdollista luoda tarvittavaa kontekstia. Niinpä vieraskielisistä soittimista (shamisen, shakuhachi, sho, gongi, sitra, koto, biwa) tai muuten oppilaiden sanavaraston ulkopuolella olevista käsitteistä (suu-urut, sylinterirummut, kaarijousi) koostuvat luettelot eivät ole pelkästään oppimisen kannalta hyödyttömiä, vaan myös omiaan etäännyttämään opetettavan kulttuurin entistä kauemmas oppilaiden tavoittamattomiin, eksotiikan ja vierauden muurin taa.

\section{Kuvituksesta: viiniä, lauluja ja (vähäpukeisia) naisia}

Oppikirjojen kuvitus on seikka, johon kansainvälisessä monikulttuurisessa musiikkikasvatuksessa ei ole kiinnitetty huomiota juuri lainkaan. Kuvituksen asema on kuitenkin merkittävä niin kauan, kun oppikirja on se musiikintuntien kulmakivi, johon tukeutuen ei-länsimaisia musiikkejakin opetetaan. Kuvitus on harvoin "harmitonta". Taitavasti käytettynä se voi toimia asiatekstiä 
oleellisesti tukevana ja havainnollistavana välineenä. Harkitsemattomasti käytettynä se on omiaan vahvistamaan erilaisia stereotypioita ja asenteita, ehkä jopa luomaan niitä. Muutama valaiseva esimerkki Musicasta: Urbaania afrikkalaista populaarimusiikkia käsittelevässä jaksossa on paljon kuvia afrikkalaisista muusikoista mutta ainoa muusikko, joka mainitaan nimeltä ja jonka kasvot tulevat tutuksi, on amerikkalainen. Tämä kertoo mielestäni "tahattomasta" ei-länsimaita väheksyvästä ja anonymisoivasta asenteesta. Esitän toisen esimerkin kysymyksen muodossa: millä tavalla kuva kevyesti pukeutuneesta, helmojaan nostelevasta naisesta hiekkarannalla liittyy aiheeseen 'Latinalaisen Amerikan musiikki"? Voisiko tämänkaltainen kuva olla esimerkiksi historian tai maantiedon kirjassa Latinalaista Amerikkaa käsittelevässä osuudessa?

Tarkastelemissani kirjoissa ei ole käytetty informatiivisessa mielessä muita kuin musiikkiin suoranaisesti liittyviä kuvia, vaikka esimerkiksi muuta kulttuuria tai yhteiskuntaa esittäviä kuvia voisi käyttää musiikin ja siihen liittyvän kulttuurin opiskelua tukevana, kontekstia luovana materiaalina. Aiheeltaan ulkomusiikillisia kuvia on siis käytetty lähinnä koristeena.

Eräs mielenkiintoinen havainto kuvien käytön suhteen on se, että samaan kulttuuriin liittyvät kuvat ovat aiheeltaan samanlaisia: Latinalaiseen Amerikkaan liittyvät kuvaavat yleensä juhlatilanteita ja Afrikkaan liittyvät muusikoita tai soittimia. Näin pienen aineiston puitteissa on vaikea sanoa, mistä tämä selvä maa- tai maanosakohtainen painottuminen johtuu, mutta se saattaa kertoa tietynlaisten kulttuuristen ennakkokäsitysten olemassaolosta.

Musiikin liittäminen perinteiseen juhlaan tai juhla-aikaan ansaitsee lähemmän tarkastelun. Juhliin liittyvä musiikki on juuri sitä musiikkia, jota käsiteltävänä olevan kulttuurin ihmisetkin mitä luultavimmin ensimmäisenä esittelisivät vierailleen. Juhlamusiikin muodot ovat siinä mielessä edustavia, että ne ovat usein laajoille ihmisryhmille tuttua, elävää musiikkiperinnettä. Musiikin oppikirjassa juhliin liittyvän musiikin esittely toistuvana periaatteena on kuitenkin kaksijakoinen asia. Jos vieraiden kulttuurien ihmisten elämä esitellään ensisijaisesti erilaisten juhlien kimarana, saattaa tuloksena olla perin eksoottinen mielikuva ihmisten elämästä ja musiikista tuossa kulttuurissa.

\section{Yhteenveto: Maailman Musiikkien Latistaminen \& Etäännyttä- minen Oy}

Suomalaisissa musiikinoppikirjoissa ei onnistuta välittämään ei-länsimaisia kulttuureita niin erilaisina kuin millaisia ne voisivat rehellisimmillään kuvattuna olla, vaan joko länsimaistuneina muunnoksina tai varta vasten länsimaisiksi "jalostettuina" versioina. Ne toimenpiteet, joilla tämä saadaan aikaan, voi jakaa kahteen ryhmään: latistaminen ja etäännyttäminen. Latistamisella tarkoitan esimerkiksi asiatekstissä ilmenevää kapeuttavaa yleistämistä tai 
musiikillisen materiaalin käsittelyä niin, että länsimaiselle estetiikalle vieras aines karsitaan pois. Etäännyttäminen, jolla tarkoitan oppilaiden näkökulman muokkaamista valmiiden länsimaisten stereotypioiden suuntaan pois pyrkimyksestä nähdä vieraat kulttuurit ennakkoluulottomasti, liittyy pääasiassa sellaisen kuvituksen käyttöön, jolla aikaansaadaan musta-valkoinen ja "turistinen" vaikutelma esiteltävästä kulttuurista. Smeds toteaa, että mitä kovemmaksi kilpailu kustantajien välillä käy, sitä enemmän kirjojen ulkoasuun kiinnitetään huomiota. Kuvien tehtävänä on tällöin tehdä kirjoista houkuttelevampia; niiden halutaan luovan tunnelmaa laulujen ympärille ja täyttävän muutoin tyhjäksi jäävää tilaa. Joskus kuvat suorastaan syrjäyttävät tekstin houkuttelevamman ulkoasun saavuttamiseksi. (1991, 98.) Vieraiden kulttuurien kohdalla tämä pyrkimys näyttää ottavan muodon, jossa nämä maat esitellään länsimaisin silmin eksoottisina turistikohteina. Tämä etäännyttää oppilaita vieraista kulttuureista ja vahvistaa länsimaisia kulttuurisia stereotypioita. Myös edellä mainitut sovitukselliset ratkaisut lisäävät mielestäni etäännyttävää vaikutusta.

Molemmissa oppikirjoissa on edellä mainituista puutteista huolimatta myös sellaisia jaksoja, joissa on päästy lähelle kansainvälisen monikulttuurisen musiikkikasvatuksen ihanteita. Tällaisena ilahduttavana poikkeuksena hahmottuu esimerkiksi Koulun musiikki 8-9:n afrikkalaista heimomusiikkia käsittelevä jakso, jossa laajemman katsauksen asemasta ollaan keskitytty yhden tansanialaisen kylän musiikkitradition esittelyyn. Pelkästään tällä ratkaisulla ollaan saavutettu havainnollisempi ja tiiviimpi ote käsiteltävään asiaan. Aihepiirin asiatekstit antavat runsaasti tietoa musiikin käyttöyhteyksistä ja kuvatun tradition historiasta. Myös aiheeseen liittyvä oheismateriaali tanssi- ja soittimenrakennusohjeineen antaa valmiuksia aiheen syvällisempään omaksumiseen. ${ }^{4}$

Musica 8-9 opettajan kirjassa on jakso, jossa valotetaan musiikin ja kulttuurin keskinäistä sidonnaisuutta harvinaisen osuvasti. Kyseisessä kohdassa vertaillaan afrikkalaisten ja lappalaisten musiikkeja.

Afrikassa heimot muodostavat tiiviin kyläyhteisön, jossa kaikki tehdään yhdessä. - - On siis luonnollista, että myös musisointi tapahtuu suuressa ryhmässä koko kyläyhteisön kesken. (Mäyry-Sipilä 1992, 65.)

Vastaavasti kerrotaan olosuhteista Lapissa, jossa asutus on hajanaista ja muita ihmisiä nähdään harvoin. Niinpä tyypillinen lappalainen muusikko on yksinäinen joikaaja. (Ibid., 65.)

Musiikin käyttöyhteyksien ja funktioiden esittely on yksi kansainvälisessä musiikkikasvatuksessa suositeltu lähestymistapa. Toistuessaan johdonmukaisesti jokaisen musiikkikulttuurin kohdalla lyhyetkin katkelmat voivat antaa oppi-

4 Tämä kirjan osa onkin laadittu yhteistyössä suomalaisen etnomusikologin Philip Donnerin kanssa. 
laille yleisen mallin riippumatta siitä, mitä musiikkia milloinkin tarkastellaan. Koulun musiikissa päästään tällaista johdonmukaisuutta lähelle, sillä vain Latinalaisen Amerikan karnevaalimusiikkia ja reggaetä käsittelevissä osuuksissa jätetään käsittelemättä musiikin funktioita. (Tosin näiden jaksojen otsikot, "Latinalais-amerikkalainen musiikki on suosittua karnevaaleissa" ja "Reggae on myös uskonnollista musiikkia" liittyvät kyllä nimenomaan musiikin funktioon.)

Jos musiikin funktioita ja käyttöyhteyksiä painotetaan suhteettomasti vain esimerkiksi afrikkalaisen musiikin kohdalla, saattaa tuloksena olla vaikutelma, jonka mukaan maailman musiikit on jaettavissa sellaisiin musiikkeihin, joilla on kiinteä yhteys ympäröivään kulttuuriin ja toisaalta niihin, joilla on löyhät yhteydet muuhun yhteiskuntaan. Afrikkalaisen musiikin kohdallahan on lähes stereotyyppisesti totuttu korostamaan sen kiinteää yhteyttä jokapäiväiseen elämään.

Kyky kohdata vieraiden kulttuurien ihmisiä on yleisin monikulttuurisen musiikkikasvatuksen tavoite. Sen teemat ovat mitä suurimmassa määrin yhtenevät kansainvälisyyskasvatuksen teemojen kanssa. Tutkimissani oppikirjoissa on tyypillistä esitellä vieraita kulttuureita länsimaisesta viitekehyksestä käsin. Vieraiden kulttuurien ihmisiä kyllä lähestytään, mutta ei mennä "liian" lähelle. Vieraat kulttuurit halutaan nähdä sellaisina kuin ne meillä on totuttu näkemään, sekä hyvässä että pahassa. Kirjojen näkökulman ja yleisten kulttuuristen käsitysten välillä vallitsee tietynlainen konsensus.

Toinen ajankohtainen ja jopa kiireellisenä pidetty monikulttuuriselle musiikkikasvatukselle asetettu tavoite on antaa oppilaille valmiuksia käsitellä sitä erilaisten musiikkien tulvaa, jonka he joutuvat kohtaamaan. Tämän tavoitteen keskiössä on ajatus siitä, että jokaisella musiikilla on oma estetiikkansa ja "kielioppinsa". Musiikki ei siis ole universaali kieli. Kuten jo aiemmin on todettu, tarkastelemissani oppikirjoissa musiikillinen aines on käsitelty siten, että kysymys musiikillisen erilaisuuden kohtaamisesta ei pääse aktualisoitumaan. Toisin sanoen vieraiden kulttuurien musiikki oppikirjoissa ei estetiikaltaan poikkea ratkaisevasti kirjan muusta musiikkimateriaalista. Tästä syystä jää kokonaan tai suureksi osaksi toteutumatta myös kaksi muuta tavoitetta: tavoite käytännön musiikillisten valmiuksien kehittämisestä ja tavoite oppilaan musiikillisen sanavaraston kasvattamisesta monikulttuurisen musiikkikasvatuksen avulla. Näissä tavoitteissa on kysymys nimenomaan sellaisten musikaalisuuden osa-alueiden harjoittamisesta, jotka jäävät helposti vähemmälle huomiolle tavanomaisen oppimateriaalin puitteissa. Tutkimissani kirjoissa tämä toteutuu ensinnäkin rytmitajua kehittävän materiaalin tarjoamisena. Etenkin latinalaisamerikkalaisissa lauluissa käytetään runsaasti rytmisoittimia. Käytetyt rytmikuviot ovat verrattain kompleksisia. Improvisaatioharjoitukset ovat toinen osa-alue, joka voidaan lukea tähän kategoriaan.

Kaikista parhaiten tutkimani oppikirjat vastaavat musiikillisen yleissivistyksen rakentamisen tavoitteeseen. Oppikirjat antavat runsaasti sellaista taustatietoa, joka valottaa erilaisten hybridimuotoisten ja/tai läntisessä maailmassa popularisoituneiden musiikkien historiaa (esim. samba, salsa, tango). Integ- 
roivan opetuksen tavoite toteutuu jossain määrin esimerkiksi opettajan materiaalissa esitettyjen soittimenrakennus- ja tanssiohjeiden muodossa.

Oppikirjojen asiateksteissä käsitellään musikaalisuuden käsitettä eri kulttuureissa vain ohimennen. Tietyt kulttuurit on esitelty leimallisesti sellaisina, joissa musikaalisuus ominaisuutena ja musiikki kuuluu kaikille. Tämä ei välttämättä johda kansainvälisessä kirjallisuudessa esitettyyn oman länsimaisen musikaalisuuskäsityksemme kyseenalaistamiseen. Oletan, että tutkimiani oppikirjoja ei ole laadittu vastaamaan etnisten vähemmistöjen kulttuurien vaalimiseen liittyviä tarpeita. Mielestäni tämä on kuitenkin näkökohta, joka tulevien kirjantekijöiden tulisi ottaa huomioon Suomessakin.

\section{Lähteet}

Anderson -Shehan Campbell (ed.) 1989. Multicultural Perspectives in Music Education. Music Educators National Conference.

Antikainen, Pia 1993. Kadonnutta erilaisuutta etsimässä. Monikulttuurinen musiikkikasvatus ja suomalaiset musiikin oppikirjat. Sibelius-Akatemia. Musiikkikasvatuksen tutkielma.

Balough, Teresa 1988. Art is a Meeting Place: Percy Grainger's Vision of a World Music and Its Implications for Music Education Today. ISME-Yearbook 15: 66-80.

Blacking, John 1973. How Musical is Man? Seattle: University of Washington Press.

Borris, Siegfried 1981. National Idioms and Universal Elements - Their Relation to Music and Music Education. ISME-Yearbook 13: 67-73.

Brown, Ernest 1993. Bess Lomax Hawes: An Activist's Perspective. Society for Ethnomusicology Newsletter: 1 (September).

Dobbs, Jack P. B. 1982. Music as Multi-Cultural Education. ISME-Yearbook 9: 142-147.

Farrel, Gerry 1986. Teaching Indian Music in the West: Problems, Approaches and Possibilities. British Journal of Music Education 3(3): 267-278.

George, Luvenia 1987. Teaching the Music of Six Different Cultures, Revised \& Updated. World Music Press.

Hoffer, Charles R. 1988. So Many Kinds of Music - So Little Time to Teach Them. ISME-Yearbook 15: 126-130.

Kalli, Sari 1991. Kansainvälisyyskasvatus musiikinopetuksessa. Jyväskylän yliopiston musiikkitieteen laitos. Julkaisematon musiikkikasvatuksen pro gradu -tutkielma.

Kwami, Robert 1985. Comparative Music Education: Viewing the Forest as well as the Trees. International Journal of Music Education 5: 47-49.

Kwami, Robert 1986. A West African Folktale in the Classroom. British Journal of Music Education 3(1): 5-18. 
Kwami, Robert 1991. An Approach to the Use of West African Musics in the Classroom Based on Age and Gender Classifications. British Journal of Music Education 8: 119-137.

Lepherd, Laurence 1988. The Challenge of Viewing World Music Education. ISME-Yearbook 15: 131-135.

Marx, Shirley 1990. A Zimbabwean Mbira: a Tradition in African Music and its Potential for Music Education. British Journal of Music Education 7(1): 25-42.

Mathias, Paul 1985. The Use of a Research Project in the Music of West Africa as a Basis for an International Music Education. International Journal of Music Education 6: 13-16.

McKeller, Donald A. 1973. Sociomusicology: The Next Horizon for Music Education. ISME-Yearbook 1: 73-79

Moisala, Pirkko 1991. Antropologinen musiikintutkimus. Teoksessa Moisala (toim.) Kansanmusiikin tutkimus, metodologian oppikirja. Helsinki: Valtion painatuskeskus, 105-137.

Moisala, Pirkko 1993. Monikulttuurinen musiikkikasvatus - nykyajan haaste kansainväliselle ja suomalaiselle musiikinopetukselle. Sibelius-Akatemian aikakauskirja SIC 1993, 197-214.

Nketia, J.H. Kwabena 1988. Exploring Intercultural Dimensions of Music Education. ISME-Yearbook 15: 96-106.

Orrenmaa, Hanne 1992. Keskiasteen musiikinopetus ja musiikinopettajien koulutus Keniassa. Sibelius-Akatemia. Musiikkikasvatuksen tutkielma.

Reeder-Lunquist, Barbara 1985. Music Education in a Multicultural Society - The United States of America. International Journal of Music Education 1985(5): 49-53.

Reeder-Lunquist, Barbara 1987. Transmission of Music Culture in Formal Educational Institutions. The World of Music 1987/1: 67-76.

Salakka, Marja 1991. 'Tyypillinen lukion musiikin oppikirja'. Sibelius-Akatemia. Musiikkikasvatuksen tutkielma.

Schwadron, Abraham A. 1984. World Musics in Education. International Journal of Music Education 1984(4): 9-12.

Seeger, Charles 1971. Studies in Musicology. Berkeley: University of California Press.

Shehan, Patricia K. 1986. Towards Tolerance and Taste: Preferences for World Music. British Journal of Music Education 1986(2): 153-163.

Smeds, Brita 1991. Principer vid val av innehåll och metoder för läroböcker i musik för årkurset 7. Sibelius-Akatemia, musiikkikasvatuksen tutkielma.

Spencer, Piers 1983. Afro-American Music in Education. ISME-Yearbook 10: 91-94.

Suomalainen toivelaulukirja 1976. Porvoo: WSOY.

Vierimaa, Irma 1991. Musiikki-ikonografinen tutkimusmetodi. Teoksessa Moisala (toim.), Kansanmusiikin tutkimus, metodologian opas. Helsinki: Valtion painatuskeskus, 240-252. 